\title{
PELATIHAN VIRTUAL PEMBUATAN LAPORAN KEUANGAN BADAN LEMBAGA AMIL ZAKAT NAHWA NUR UNTUK MENARIK MUZAKKI BERDONASI
}

\author{
Rudi Sanjaya'), Krida Puji Rahayu'), Agustina Mogi'), Arif Surahman'), \\ Sulistiyani ${ }^{5)}$ \\ 1,2,3,4,5 Program Studi Manajemen, Fakultas Ekonomi, Universitas Pamulang
}

\begin{abstract}
Abstrak
Tujuan utama dari laporan keuangan adalah menyediakan informasi yang relevan untuk pihak-pihak yang berkepentingan baik pihak internal maupun eksternal misalnya muzakki, pemerintah, pihak lain yang menyediakan sumber daya bagi OPZ dan juga masyarakat. Fokusnya yaitu pada pelatihan virtual pembuatan laporan keuangan badan Lembaga Amil Zakat Nahwa Nur untuk menarik muzakki berdonasi. Tujuan utamanya yaitu memberikan pemahaman, pengarahan, dan pengetahuan kepada para peserta mengenai pentingnya pelatihan virtual pembuatan laporan keuangan badan Lembaga Amil Zakat Nahwa Nur untuk menarik muzakki berdonasi. Pandemi COVID-19 merupakan musibah yang memilukan seluruh penduduk bumi. Seluruh segmen kehidupan manusia di bumi terganggu, tanpa kecuali badan LAZ Nahwa Nur. Solusi atas permasalahan ini adalah memberikan pengetahuan dan ketrampilan membuat laporan keuangan kepada Rumah Lembaga Amil Zakat Nahwa Nur Depok Jaya. Metode pelaksanaan pelatihan dan pendampingan ini terutama menggunakan metode kegiatan action research secara virtual. Tim pelaksana melakukan kegiatan pemberian materi sambil melakukan analisis untuk pemecahan masalah yang dihadapi. Metode pemberi materi dilakukan dengan ceramah, tanya jawab interaktif, demonstrasi dan penyelesaian kasus secara online. Berdasar dari identifikasi awal ini maka pemberian pengetahuan dan ketrampilan tentang cara membuat laporan keuangan sangatlah tepat, karena dengan ketrampilan membuat laporan keuangan ini peserta diharap bisa membuat laporan keuangan lembaganya, agar calon para muzakki yakin bahwa lembaga mereka layak untuk didonasi. Laporan keuangan dapat dikatakan sebagai hasil akhir dari suatu proses akuntansi
\end{abstract}

Kata Kunci: Laporan Keuangan, Pelatihan Virtual, Lembaga Amil Zakat

\begin{abstract}
The main objective of financial reports is to provide relevant information to interested parties, both internal and external, such as muzakki, government, other parties who provide resources to OPZ and also the public. The focus is on virtual training in making financial reports of the Nahwa Nur Amil Zakat Institution to attract muzakki to donate. The main objective is to provide understanding, direction, and knowledge to the participants about the importance of virtual training in making financial reports of the Nahwa Nur Amil Zakat Institute to attract muzakki to donate. The COVID-19 pandemic is a devastating disaster for all inhabitants of the earth. All segments of human life on earth are disturbed, without exception LAZ Nahwa Nur. The solution to this problem is to provide knowledge and skills in making financial reports to the Rumah Sakit Amil Zakat Nahwa Nur Depok Jaya. The method of implementing this training and mentoring mainly uses the method of virtual action research activities. The implementing team carries out activities providing material while analyzing the problem solving at hand. The method of providing material is
\end{abstract}


done by lectures, interactive question and answer, demonstrations and online case resolution. Based on this initial identification, the provision of knowledge and skills on how to make financial reports is very appropriate, because with the skills in making financial reports, participants are expected to be able to make financial reports of their institutions, so that prospective muzakki are sure that their institutions are worthy of donation. Financial statements can be said to be the end result of an accounting process

Keywords: Financial Reports, Virtual Training, Amil Zakat Institution

Correspondence author: Krida Puji Rahayu, paknyaknyamin@gmail.com, Tangerang, Indonesia

\section{PENDAHULUAN}

\subsection{Latar Belakang}

Saat ini Corona menjadi pembicaraan yang hangat. Di belahan bumi manapun, corona masih mendominasi ruang publik. Dalam waktu singkat saja, namanya menjadi trending topik, dibicarakan di sana-sini, dan diberitakan secara masif di media cetak maupun elektronik. Severe Acute Respiratory Syndrome Coronavirus 2 (SARS-COV-2) yang lebih dikenal dengan nama virus corona adalah jenis baru dari coronavirus yang menyebabkan penyakit menular ke manusia. Covid-19 adalah penyakit menular yang disebabkan oleh jenis coronavirus yang baru ditemukan. Walaupun lebih banyak menyerang ke lansia, virus ini sebenarnya bisa juga menyerang siapa saja, mulai dari bayi, anak-anak, hingga orang dewasa. Virus corona ini bisa menyebabkan ganguan ringan pada sistem pernapasan, infeksi paru-paru yang berat, hingga kematian.

Dampak wabah virus Corona (Covid-19) tidak hanya merugikan sisi kesehatan. Virus yang bermula dari Kota Wuhan, Tiongkok, ini bahkan turut mempengaruhi perekonomian negara-negara di seluruh dunia, tak terkecuali Indonesia. Covid-19 merupakan penyakit menular yang disebabkan oleh virus bernama SARS-COV-2, atau seringkali disebut Virus Corona. Virus Corona sendiri merupakan keluarga virus yang sangat besar. Ada yang menginveksi hewan, seperti kucing dan anjing, namun ada pula jenis Virus Corona yang menular ke manusia, seperti yang terjadi pada Covid-19. Covid-19 merupakan penyakit baru, jadi manusia belum punya kekebalan tubuh terhadap Virus SARS-Cov-2. Vaksin dan obatnya belum ditemukan. Saat ini, peneliti di penjuru dunia masih berlombalomba mencari vaksin dan obatnya. Kurangnya sosialisasi dan tanggapnya pemerintah terhadap virus ini menyebabkan hampir di seluruh dunia terinfeksi virus Covid-19. Selain itu, masyarakat yang kurang sadar akan pentingnya menjaga kesehatan dan kebersihan.

Ekonomi global dipastikan melambat, menyusul penetapan dari WHO yang menyebutkan wabah Corona sebagai pandemi yang mempengaruhi dunia usaha. Di Indonesia, pemerintah mencoba melakukan berbagai upaya untuk menekan dampak virus Corona terhadap industri. Beberapa stimulus ekonomi diluncurkan, bahkan Presiden Joko Widodo meminta seluruh pihak untuk melakukan social distancing 
termasuk Work From Home (WFH) dan beberapa Kepala Daerah memutuskan untuk meliburkan kegiatan belajar mengajar.

Peraturan Gubernur Jawa Barat Nomor 27 Tahun 2020 tentang: Pedoman Pembatasan Sosial Berskala Besar dalam penanganan Covid19 di daerah Kabupaten Bogor, daerah kota Bogor, daerah kota Depok, daerah Kabupaten Bekasi dan daerah kota Bekasi. Isinya diantaranya sebagai berikut:

1). Aktivitas di Luar Rumah

a. Penghentian sementara kegiatan di sekolah dan/atau institusi pendidikan lainnya/belajar di rumah.

b. Penghentian sementara aktivitas bekerja di tempat kerja/kantor dan diganti bekerja di rumah/Work From Home.

c. Tempat ibadah di tutup untuk umum, ibadah di lakukan di rumah masing-masing.

d. Penghentian sementara aktivitas penduduk di tempat/fasilitas umum dengan audiens di atas 5 orang.

e. Penghentian sementara aktivitas sosial dan budaya yang menimbulkan kerumunan orang.

f. Pembatasan penggunaan moda transportasi untuk pergerakan orang dan barang.

2). Moda Transportasi

a. Untuk pemenuhan kebutuhan pokok

b. Jaga jarak aman antar penumpang

c. Jumlah penumpang dibatasi $50 \%$.

3). Pengecualian seluruh kantor/instansi pemerintahan, baik pusat maupun daerah berdasarkan pengaturan dari kementrian terkait, BUMN/BUMD yang turut serta dalam penanganan Covid-19 dan/atau dalam pemenuhan kebutuhan pokok masyarakat, pelaku usaha yang bergerak pada sektor:

a. Kesehatan

b. Energi

c. Bahan pangan/makanan/minuman

d. Keuangan

e. Perhotelan

f. Pelayanan dasar, utilitas publik dan industri yang ditetapkan sebagai objek vital nasional dan objek tertentu

g. Organisasi kemasyarakatan lokal dan internasional yang bergerak pada sektor kebencanaan dan.atau sosial

h. Kebutuhan sehari-hari

i. Industri strategis

j. Logistik

k. Konstruksi

1. Komunikasi dan teknologi informasi

Berkenaan dengan penyebaran Covid-19 yang semakin meningkat di Indonesia, maka kesehatan lahir dan batin siswa, guru, kepala sekolah dan seluruh warga sekolah menjadi pertimbangan utama dalam pelaksanaan kebijakan pendidikan. Oleh karena itu, Kemendikbud mengeluarkan Surat Edaran Nomor 36962/MPK.A/HK/2020, tentang Pembelajaran secara Daring dan Bekerja dari Rumah dalam Rangka Pencegahan Penyebaran Corona Virus Desease (Covid-19), tanggal 17 Maret 2020 dengan ketentuan sebagai berikut:

1). Memberlakukan pembelajaran secara daring dari rumah bagi mahasiswa; 
2). Pegawai dan dosen melakukan aktivitas bekerja, mengajar atau memberi kuliah dari rumah (Bekerja dari Rumah/BDR) melalui video conference, digital documents, dan sarana daring lainnya.

3). Pelaksanaan BDR tidak mempengaruhi tingkat kehadiran (dipandang sama seperti bekerja di kantor, sekolah, atau perguruan tinggi), tidak mengurangi kinerja, dan tidak mempengaruhi tunjangan kinerja; dan

4). Dalam kegiatan Pengabdian Kepada Masyarakat kami melakukan kerjasama dengan Rumah Lembaga Amil Zakat Nahwa Nur Depok Jaya. Berdasarkan peraturan pemerintah Pusat dan Pemerintah Daerah Jawa Barat dikarenakan adanya Pandemi Covid-19 warga dilarang keluar rumah. Hal ini dilakukan untuk mencegah penyebaran Covid-19 di daerah sekitarnya. Hal ini sangat berdampak untuk warga yang kesehariannya sebagai warga yang tergolong sebagai warga dhuafa. Dari hasil survei dan wawancara melalui Rumah Lembaga Rumah Lembaga Amil Zakat Nahwa Nur Depok Jaya bahwa permasalahan yang ada sekarang ini dan masih berlanjut salah satunya yaitu warga yang didaerah perkampungan Parung Panjang tidak mendapatkan penghasilan, dikarenakan dampak ekonomi atas pandemik covid-19.

5). Zakat merupakan salah satu ibadah pokok dalam Islam yang dapat menjadi pilar utama dan tool untuk menegakkan keadilan dalam kehidupan sosial serta dapat meningkatkan kesejahteraan umat. Zakat menurut istilah fiqh Islam adalah sejumlah harta tertentu yang wajib dikeluarkan dari kekayaan orangorang kaya (the have) untuk diserahkan kepada orang-orang yang berhak menerimanya menurut aturan-aturan atau syariat Allah SWT (Anshori, 2006: 12). Menurut PSAK No. 109, tujuan zakat yang mulia tersebut akan dapat tercapai apabila dalam pengelolaan zakat dilakukan secara baik dan profesional (good zakat governance), artinya bahwa zakat seharusnya dikelola secara melembaga sesuai dengan syariat Islam, amanah, kemanfaatan, keadilan, kepastian hukum, terintegrasi, dan akuntabilitas.

6). Pengelolaan Zakat menurut Undang-Undang No. 23 Tahun 2011 adalah suatu kegiatan perencanaan, pelaksanaan dan pengorganisasian dalam pengumpulan, pendistribusian dan pendayagunaan zakat. Dalam melaksanakan tugas dan fungsinya, BAZNAS dapat dibantu oleh UnitPengumpul Zakat (UPZ). UPZ merupakan satuan organisasi yang dibentuk oleh BAZNAS untuk membantu mengumpulkan zakat.

7). Salah satu kegiatan utama dari beberapa kegiatan yang dilakukan oleh organisasi pengelola zakat adalah pengumpulan zakat. Aktivitas itu sangat tergantung kepada para donatur (Muzakki). Selama masih ada muzakki yang menyalurkan zakatnya pada OPZ maka fungsi OPZ akan berjalan secara baik, namun sebaliknya ketika tidak ada muzakki yang menyalurkan zakatnya pada OPZ maka OPZ tidak akan berfungsi sebagaimana mestinya.

Untuk itu, kami Dosen Universitas Pamulang dan mahasiswa mengadakan Pengabdian Kepada Masyarakat (PKM) bekerjasama dengan LAZ Nahwa Nur dengan judul "Pelatihan Virtual Pembuatan Laporan Keuangan Badan Lembaga Amil Zakat Nahwa Nur Untuk Menarik Muzakki Berdonasi”.

\subsection{Perumusan Masalah}

Berdasarkan latar belakang masalah tersebut maka dapat dirumuskan masalah sebagai berikut, "Bagaimana memberikan pemahaman, pengarahan, dan 
pengetahuan kepada para peserta mengenai pentingnya pelatihan virtual pembuatan laporan keuangan badan Lembaga Amil Zakat Nahwa Nur untuk menarik muzakki berdonasi?"

\subsection{Tujuan Pengabdian Kepada Masyarakat}

Berdasarkan perumusan masalah di atas maka Pengabdian kepada Masyarakat (PKM) ini bertujuan untuk : Memberikan pemahaman, pengarahan, dan pengetahuan kepada para peserta mengenai pentingnya pelatihan virtual pembuatan laporan keuangan badan Lembaga Amil Zakat Nahwa Nur untuk menarik muzakki berdonasi.

\subsection{Manfaat Pengabdian Kepada Masyarakat}

Manfaat adanya kegiatan Pengabdian kepada Masyarakat yang telah dilaksanakan adalah sebagai berikut

1). LAZ Nahwa Nur

Menambah khasanah ilmu pengetahuan agar dapat digunakan sebagai bahan masukan dan pertimbangan bagi lembaga dalam rangka pembuatan laporan keuangan badan Lembaga Amil Zakat Nahwa Nur untuk menarik muzakki berdonasi.

2). Universitas Pamulang

Khususnya Dosen Universitas Pamulang bisa mengaplikasikan ilmunya dalam bidang akuntansi dan keuangan dan membentuk masyarakat yang terdidik. Mahasiswa juga terlibat dalam pengabdian masyarakat ini sehingga mereka bisa membantu dalam mempraktekan ilmu yang sudah didapatkan di dalam kelas maupun di luar kelas. Selain itu, dengan adanya Pengabdian Kepada Masyarakat LAZ Nahwa Nur yang berkelanjutan menjalin kerjasama dengan Universitas Pamulang melalui Perjanjian Kerja Sama antara LAZ Nahwa Nur dengan Universitas Pamulang.

\subsection{Tinjauan Pustaka}

\subsubsection{Tinjauan Tentang Organisasi Pengelola Zakat (OPZ) Dalam Undang- Undang No. 23 Tahun 2011}

Masalah pengelolaan zakat dan Organisasi Pengelola Zakat (OPZ) pada awalnya diatur dalam Undang-Undang No. 38 tahun 1999, namun karena Undang-Undang tersebut dinilai sudah tidak sesuai lagi dengan perkembangan dan kebutuhan hukum dalam masyarakat maka UU tersebut disempurnakan menjadi Undang-Undang no. 23 Tahun 2011 tentang Pengelolaan Zakat. Dalam UU tersebut, yang dimaksud pengelolaan zakat adalah kegiatan perencanaan, pelaksanaan, dan pengoordinasian dalam pengumpulan, pendistribusian, dan pendayagunaan zakat yang bertujuan untuk meningkatkan efektivitas dan efisiensi pelayanan dalam pengelolaan zakat dan meningkatkan manfaat zakat untuk mewujudkan kesejahteraan masyarakat dan penanggulangan kemiskinan. Sedangkan lembaga yang 
berwenang melakukan tugas pengelolaan zakat, infak dan sedekah disebut dengan Organisasi Pengelola Zakat.

LAZ adalah lembaga yang dibentuk masyarakat yang memiliki tugas membantu pengumpulan, pendistribusian dan pendayagunaan zakat. Pembentukan LAZ wajib mendapat izin Menteri atau pejabat yang ditunjuk oleh Menteri. LAZ wajib melaporkan pelaksanaan pengumpulan, pendistribusian, dan pendayagunaan zakat yang telah diaudit kepada BAZNAS secara berkala. Dalam melaksanakan tugas dan fungsinya, BAZNAS dapat dibantu Unit Pengumpul Zakat (UPZ). UPZ merupakan satuan organisasi yang dibentuk oleh BAZNAS untuk membantu mengumpulkan zakat. Berkaitan dengan pelaporan pelaksanaan pengelolaan zakat, infak/sedekah dan dana sosial keagamaan lainnya, BAZNAS kabupaten/kota wajib menyampaikan pelaksanaan pengelolaan ZIS dan dana sosial keagamaan lainnya kepada BAZNAS provinsi dan pemerintah daerah secara berkala.

Selanjutnya BAZNAS provinsi wajib menyampaikan laporan pelaksanaan ZIS dan dana sosial keagamaan lainnya kepada BAZNAS dan pemerintah daerah secara berkala. LAZ wajib menyampaikan laporan pelaksanaan pengelolaan ZIS dan dana sosial keagamaan lainnya kepada BAZNAS dan pemerintah daerah secara berkala. Selanjutnya BAZNAS wajib menyampaikan pelaksanaan pengelolaan ZIS dan dana sosial keagamaan lainnya kepada Menteri secara berkala. Laporan neraca tahunan BAZNAS diumumkan melalui media cetak atau media elektronik. Untuk melakukan tugasnya, BAZNAS dibiayai dengan Anggaran Pendapatan dan Belanja Negara dan Hak Amil. Sedangkan BAZNAS provinsi dan BAZNAS kabupaten/kota dibiayai dengan Anggaran Pendapatan dan Belanja Daerah dan Hak Amil, serta juga dapat dibiayai dengan Anggaran Pendapatan dan Belanja Negara. Pembinaan dan pengawasan terhadap BAZNAS, BAZNAS provinsi, BAZNAS kabupaten/kota, dan LAZ dilaksanakan oleh Menteri. Gubernur dan Bupati/Walikota melaksanakan pembinaan dan pengawasan terhadap BAZNAS provinsi, BAZNAS kabupaten/kota, dan LAZ sesuai dengan kewenangannya. Pembinaan tersebut meiputi fasilitasi, sosialisasi dan edukasi. Masyarakat dapat berperan serta dalam pembinaan dan pengawasan terhadap BAZNAS dan LAZ. Pengawasan yang dimaksud pertama, berupa akses terhadap informasi tentang pengelolaan zakat yang dilakukan oleh BAZNAS dan LAZ. Kedua,penyampaian informasi apabila terjadi penyimpangan dalam pengelolaan zakat yang dilakukan oleh BAZNAS dan LAZ.

Hasil dari uji material oleh Mahkamah Konstitusi terhadap UU Pengelolaan Zakat tersebut dapat diringkas:

1) Dikuatkannya peran BAZNAS sebagai pemain utama pengelolaan zakat di Indonesia,

2) Masyarakat diperkenankan mengelola zakat selama mendapatkan izin/pengukuhan dari pemerintah (dalam bentuk LAZ), atau kalau di daerah yang belum terjamah operasi BAZNAS dan LAZ, maka pengelola zakat lainnya (seperti masjid, pesantren dan kyai) diharuskan memberitahukan kepada pejabat terkait,

3) Persyaratan pengukuhan LAZ tidak mensyaratkan badan hukumnya harus ormas atau perkumpulan, tapi dapat juga berbentuk yayasan, 
4) Masyarakat lainnya dianjurkan untuk menjadi Unit Pengelola Zakat (UPZ), baik UPZ BAZNAS maupun UPZ LAZ,

5) Menegaskan BAZNAS sebagai "coordinator administratif" pengelola zakat di Indonesia,

6) Pelaksanaan sanksi pidana terhadap pengelola zakat dilakukan secara bertahap,

Semua pengelola zakat yang telah berijin/dikukuhkan sebagaimana poin (2) dan menjadi UPZ sebagaimana point (4) tidak akan mendapatkan sanksi pidana (Juwaini, 2013).

\subsubsection{Peran sistem Informasi Akuntansi bagi Organisasi Pengelola Zakat (OPZ)}

Salah satu alat yang dapat digunakan OPZ untuk menumbuhkan kepercayaan umat terhadap kualitas OPZ adalah dengan mengaplikasikan suatu sistem akuntansi yang baik dalam pengelolaan zakat. Sistem akuntansi yang baik diharapkan pengelolaan zakat oleh OPZ akan menjadi lebih efektif, efisien dan lebih transparan (jelas sumber dan penggunaan dana zakat) serta lebih akuntabel (dapat dipertanggungjawabkan). Sistem akuntansi adalah formulir-formulir, catatan-catatan, prosedur-prosedur dan alat-alat yang digunakan untuk mengolah data mengenai usaha suatu kegiatan ekonomis dengan tujuan untuk menghasilkan umpan balik dalam bentuk laporanlaporan yang diperlukan oleh manajemen untuk mengawasi usahanya dan pihak-pihak yang berkepentingan yang lain (Muzakki, pemerintah, mustahik, masyarakat/umat) untuk menilai hasil operasional (Howard F. Settler dalam Hariningsih, 2006: 3). Menurut Mulyadi (2001: 3) sistem akuntansi adalah organisasi formulir, catatan dan laporan yang dikoordinasi untuk menyediakan inforrmasi keuangan yang dibutuhkan oleh manajemen guna memudahkan pengelolaan perusahan.

Ikatan Akuntan Indonesia (IAI) sebagai organisasi profesi akuntan di Indonesia berupaya memberikan kontribusi dalam rangka mewujudkan sistem akuntansi yang baik dari suatu OPZ. Pada tahun 2010, IAI menerbitkan Pernyataan Standar Akuntansi Keuangan (PSAK) No. 109. PSAK ini bertujuan untuk mengatur tentang akuntansi zakat, infaq dan shadaqah yakni mengatur pengakuan, pengukuran, penyajian dan pengungkapan transaksi zakat dan infak/sedekah yang berlaku bagi Organisasi Pengelola Zakat yang berkewajiban menghimpun dan menyalurkan zakat dan infak/sedekah. PSAK tersebut diterbitkan sebagai pedoman standardisasi dalam pencatatan transaksi dan penyusunan laporan keuangan yang dibuat oleh Organisasi Pengelola Zakat. Dengan adanya standardisasi tersebut maka akan terjadi keseragaman (uniformity) dan keterbandingan (comparability) dalam pencatatan dan pelaporan keuangan yang dibuat oleh Organisasi Pengelola Zakat yang ada di Indonesia, hal ini juga dapat membantu memudahkan akuntan publik dalam melakukan audit atas laporan keuangan OPZ.

Standar akuntansi ZIS yang berlaku saat ini dan digunakan oleh OPZ sebagai pedoman dalam pembukuan dan pelaporan keuangannya adalah PSAK No. 109 yang dikeluarkan oleh Ikatan Akuntan Indonesia (IAI) pada 
tahun 2010. Penerbitan PSAK ini telah mengalami proses yang cukup lama kurang lebih empat tahun dari waktu penyusunannya, dimulai dengan disusunnya Eksposure Draft-nya (ED) yang diterbitkan sejak tahun 2008. Namun, saat ini tidak semua OPZ yang ada di Indonesia dapat menerapkan PSAK no. 109. Hal tersebut karena sebagian OPZ mengalami beberapa kendala dalam penerapannya. Salah satu faktor kendalanya adalah adanya kesulitan dalam sumber daya manusia yang dimiliki OPZ. Akuntansi zakat yang ada dalam Pernyataan Standar Akuntansi Keuangan (PSAK) No. 109 bertujuan untuk mengatur pengakuan, pengukuran, penyajian dan pengungkapan transaksi zakat dan infak/sedekah. PSAK ini berlaku untuk amil yakni suatu organisasi/entitas pengelola zakat yang pembentukannya dan pengukuhannya diatur berdasarkan peraturan perundang-undangan yang dimaksudkan untuk mengumpulkan dan menyalurkan zakat dan infak/sedekah, bukan untuk entitas syariah yang menerima dan menyalurkan ZIS tetapi bukan kegiatan utamanya. Untuk entitas tersebut mengacu ke PSAK 101 mengenai Penyajian Laporan Keuangan Syariah. Amil yang tidak mendapatkan izin juga dapat menerapakan PSAK No. 109. PSAK ini merujuk kepada beberapa fatwa MUI (Washilah dan Nurhayati : 2013) yaitu: 1) Fatwa MUI no. 8/2011 tentang amil zakat, 2) Fatwa MUI No. 13/2011 tentang Hukum Zakat atas Harta Haram, 3) Fatwa MUI No. 14/2011 tantang Penyaluran Harta Zakat dalam bentuk Aset Kelolaan. 4) Fatwa MUI No.15/2011 tentang penarikan, pemeliharaan dan penyaluran harta zakat

\section{METODE PELAKSANAAN}

\subsection{Kerangka Pemecahan Masalah}

Salah satu alat yang dapat digunakan OPZ untuk menumbuhkan kepercayaan umat terhadap kualitas OPZ adalah dengan mengaplikasikan suatu sistem akuntansi yang baik dalam pengelolaan zakat. Sistem akuntansi yang baik diharapkan pengelolaan zakat oleh OPZ akan menjadi lebih efektif, efisien dan lebih transparan (jelas sumber dan penggunaan dana zakat) serta lebih akuntabel (dapat dipertanggungjawabkan). Sistem akuntansi adalah formulir-formulir, catatancatatan, prosedur-prosedur dan alat-alat yang digunakan untuk mengolah data mengenai usaha suatu kegiatan ekonomis dengan tujuan untuk menghasilkan umpan balik dalam bentuk laporan-laporan yang diperlukan oleh manajemen untuk mengawasi usahanya dan pihak-pihak yang berkepentingan yang lain (Muzakki, pemerintah, mustahik, masyarakat/umat) untuk menilai hasil operasional (Howard F. Settler dalam Hariningsih, 2006: 3). Menurut Mulyadi (2001: 3) sistem akuntansi adalah organisasi formulir, catatan dan laporan yang dikoordinasi untuk menyediakan inforrmasi keuangan yang dibutuhkan oleh manajemen guna memudahkan pengelolaan perusahan.

Pengakuan dan Pengukuran (PSAK 109) tentang Akuntansi Untuk Zakat:

1). Penerimaan zakat diakui pada saat kas atau aset nonkas diterima dan diakui sebagai penambah dana zakat. Jika diterima dalam bentuk kas, diakui sebesar jumlah yang diterima tetapi jika dalam bentuk non kas sebesar nilai wajar 
aset. Penentuan nilai wajar aset nonkas yang diterima menggunakan harga pasar. Jika harga pasar tidak tersedia, maka dapat menggunakan metode penentuan nilai wajar lainnya sesuai dengan PSAK yang relevan.

2). Jika muzakki menentukan mustahik yang harus menerima penyaluran zakat melalui amil, maka aset zakat yang diterima seluruhnya diakui sebagai dana zakat dan tidak ada bagian amil atas zakat yang diterima dan amil dapat menerima ujrah atas kegiatan penyaluran zakat. Jika atas jasa tersebut amil mendapatkan ujrah/fee, maka diakui sebagai penambah dana amil.

3). Penurunan nilai aset zakat diakui sebagai 1) Pengurang dana zakat, jika terjadi tidak disebabkan oleh kelalaian amil; 2) Kerugian dan pengurang dana amil, jika disebabkan oleh kelalaian amil.

4). Zakat yang disalurkan kepada mustahik, diakui sebagai pengurang dana zakat dengan keterangan sesuai dengan kelompok mustahik termasuk jika disalurkan kepada Amil, sebesar:

a. Jumlah yang diserahkan, jika pemberian dilakukan dalam bentuk kas, jurnal,

b. Jumlah tercatat, jika pemberian dilakukan dalam bentuk aset nonkas, jurnal:

5). Amil berhak mengambil bagian dari zakat untuk menutup biaya operasional dalam menjalankan fungsinya.

6). Beban penghimpunan dan penyaluran zakat harus diambil dari porsi amil.

7). Zakat dikatakan telah disalurkan kepada mustahik-non-amil hanya bila telah diterima oleh mustahik-non-amil tersebut. Apabila zakat disalurkan melalui amil lain, maka diakui sebagai piutang penyaluran dan bagi amil yang menerima diakui sebagai liabilitas (utang) penyaluran. Piutang dan liabilitas berkurang ketika zakat disalurkan. Amil lain tidak berhak mengambil bagian dari dana zakat, namun dapat memperoleh ujrah dari amil sebelumnya.

8). Dana zakat yang disalurkan dalam bentuk perolehan asset tetap (asset kelolaan) diakui sebagai:

a. Penyaluran zakat seluruhnya, jika asset tetap tersebut diserahkan untuk dikelola kepada pihak lain yang tidak dikendalikan amil.

b. Penyaluran secara bertahap diukur sebesar penyusutan asset tetap tersebut sesuai dengan pola pemanfaatannya, jika asset tetap tersebut masih dalam pengendalian amil atau pihak lain yang dikendalikan amil.

9). Amil harus mengungkapkan hal-hal berikut terkait dengan transaksi zakat, tetapi tidak terbatas pada: 1) Kebijakan penyaluran zakat, seperti penentuan skala prioritas penyaluran zakat dan mustahik nonamil; 2) Kebijakan penyaluran zakat untuk amil dan mustahiq nonamil, seperti persentase pembagian, alasan, dan konsistensi kebijakan; 3) Metode penentuan nilai wajar yang digunakan untuk penerimaan zakat berupa asset nonkas.

\section{Realisasi Pemecahan Masalah}

Solusi atas permasalahan ini adalah memberikan pengetahuan dan ketrampilan membuat laporan keuangan kepada Rumah Lembaga Rumah Lembaga Amil Zakat Nahwa Nur Depok Jaya. Metode pelaksanaan pelatihan dan pendampingan ini terutama menggunakan metode kegiatan action research secara virtual. Tim pelaksana melakukan kegiatan pemberian materi sambil 
melakukan analisis untuk pemecahan masalah yang dihadapi. Metode pemberi materi dilakukan dengan ceramah, tanya jawab interaktif, demonstrasi dan penyelesaian kasus secara online. Berdasar dari identifikasi awal ini maka pemberian pengetahuan dan ketrampilan tentang cara membuat laporan keuangan sangatlah tepat, karena dengan ketrampilan membuat laporan keuangan ini peserta diharap bisa membuat laporan keuangan lembaganya, agar calon para muzakki yakin bahwa lembaga mereka layak untuk didonasi.

Laporan keuangan amil zakat dapat menjadi media komunikasi antara lembaga amil dengan pihak lainnya, karena laporan keuangan ZIS merupakan bentuk pertanggungjawaban operasional dari suatu lembaga amil yaitu kegiatan pengumpulan dan penyaluran dana zakat, infak dan sedekah (ZIS). Supaya laporan keuangan itu transparan dan akuntabel maka harus ada standar akuntansi yang mengatur tentang hal tersebut. Penyusunan laporan keuangan lembaga amil ZIS mengacu kepada PSAK No. 109, dan apabila ada hal-hal yang tidak diatur dalam PSAK 109 maka dapat menggunakan PSAK terait sepanjang tidak bertentangan dengan prinsip syariah Islam. Komponen laporan keuangan dalam PSAK 109 terdiri dari laporan posisi keuangan (Neraca), Laporan Perubahan Dana, Laporan Perubahan Aset Kelolaan, Laporan Arus Kas dan Catatan Atas Laporan Keuangan. Dalam penyajian laporan keuangan, lembaga Amil menyajikan dana zakat, dana infak/sedekah, dana amil dan dana nonhalal secara terpisah dalam neraca (laporan posisi keuangan).

Kepercayaan merupakan faktor penting dalam menumbuhkan kesadaran, kepatuhan dan motivasi masyarakat Muslim dalam menunaikan kewajiban ZISnya melalui organisasi resmi atau formal (BAZNAS dan LAZ). Semakin tinggi kepercayaan umat terhadap OPZ maka akan semakin tinggi pula kesadaran, kepatuhan dan motivasi mereka untuk secara sukarela menyalurkan ZISnya ke OPZ formal. Transparansi dan akuntabilitas merupakan faktor penting yang dibutuhkan masyarakat untuk menumbuhkan kepercayaan mereka kepada OPZ. Bentuk transparansi dan akuntabilitas OPZ ditunjukkan dengan laporan keuangan ZIS yang dibuat oleh OPZ disetiap periode dan dipublikasikan melalui berbagai media massa baik media cetak maupun elektronik. Untuk menghasilkan suatu laporan keuangan ZIS yang baik, maka dibutuhkan penerapan sistem akuntansi yang baik pula. Sistem akuntansi merupakan proses akuntansi yang diawali dari identifikasi transaksi sampai dengan penyusunan laporan keuangan. Dalam pelaksanaan proses akuntansi dibutuhkan standar/pedoman akuntansi yang mengatur tentang pengakuan, pengukuran, penyajian dan pengungkapan transaksi zakat dan infak/sedekah.

Standar akuntansi ZIS yang berlaku di Indonesia yaitu PSAK No. 109 tentang akuntansi ZIS yang dikeluarkan oleh Ikatan Akuntan Indonesia (IAI) dan disyahkan pada tahun 2010. PSAK ini berlaku untuk amil yakni suatu organisasi/entitas pengelola zakat yang pembentukannya dan pengukuhannya diatur berdasarkan peraturan perundang-undangan yang dimaksudkan untuk mengumpulkan dan menyalurkan zakat dan infak/sedekah, bukan untuk entitas syariah yang menerima dan menyalurkan ZIS tetapi bukan kegiatan utamanya. Dengan PSAK 109 tersebut diharapkan dapat tercipta keseragaman (uniformity) dan keterbandingan (comparability) laporan keuangan yang dibuat dan supaya OPZ juga siap untuk diaudit oleh akuntan publik. Saat ini sebagian OPZ dalam membuat laporan keuangan masih belum menerapkan PSAK 109, sebagian OPZ masih menggunakan pelaporan keuangan yang sederhana sehingga bentuk dan format pelaporan tiap OPZ menjadi berbeda-beda. Faktor penyebab belum diterapkannya PSAK 109 di 
Pelatihan Virtual Pembuatan Laporan Keuangan Badan Lembaga Amil Zakat Nahwa Nur Untuk Menarik

sebagian OPZ adalah kesulitan dalam menerapkannya karena kendala sumber daya manusia yang dimiliki OPZ. Sehingga untuk mengatasi permasalahan tersebut diperlukan pelatihan dan pendampingan bagi OPZ terkait penerapan PSAK 109

\section{Khalayak Sasaran}

Kami mewakili dosen Universitas Pamulang mengadakan kerjasama dengan LAZ Nahwa Nur untuk memberikan pemahaman, pengarahan, dan pengetahuan kepada para peserta mengenai pentingnya, pelatihan virtual pembuatan laporan keuangan badan Lembaga Amil Zakat Nahwa Nur untuk menarik muzakki berdonasi.

Setelah ada kesepakatan di antara kedua belah pihak mengenai acara tersebut, maka kami yang terdiri dari lima orang Dosen Tetap Universitas Pamulang yang terdiri dari Rudi Sanjaya, S.E., M.M., Krida Puji Rahayu, S.Pd., M.Pd., Agustina Mogi, S.Si., M.M., Arif Surahman, S.E., M.S.M., Sulistiyani, S.Pd., M.Pd., bersama dengan beberapa mahasiswa dari Universitas Pamulang melakukan diskusi dan membentuk panitia untuk kelancaran acara tersebut

\section{Tempat Dan Waktu}

Tempat pelaksanaan kegiatan Pengabdian Kepada Masyarakat yang kami lakukan bekerjasama dengan LAZ Nahwa Nur di laksanakan secara virtual melalui aplikasi Zoom meeting.

Acara tersebut terselenggara dari tanggal 10 s.d 12 November 2020, dengan rincian run down acara sebagai berikut:

Tabel 1 Jadwal Acara

\begin{tabular}{|c|c|c|}
\hline WAKTU & URAIAN KEGIATAN & KETERANGAN \\
\hline \multicolumn{3}{|c|}{ Selasa, 10 November 2020} \\
\hline $08.00-08.30$ & Registrasi Peserta & Mahasiswa UNPAM \\
\hline $08.30-08.40$ & Pembukaan acara & Mc: Krida Puji Rahayu, S.Pd., M.Pd \\
\hline $08.40-09.00$ & $\begin{array}{l}\text { Pembacaan Ayat-ayat Suci } \\
\text { Al-Qur'an }\end{array}$ & Arif Surahman, S.E., M.S.M. \\
\hline $09.00-09.30$ & $\begin{array}{l}\text { Sambutan General Manager } \\
\text { LAZ Nahwa Nur }\end{array}$ & Yusuf Cakhyono \\
\hline $09.30-10.00$ & Sambutan Ketua Pelaksana & Rudi Sanjaya, S.E., M.M. \\
\hline $10.00-12.00$ & Pengenalan acara Pelatihan & Krida Puji Rahayu, S.Pd., M.Pd. \\
\hline $12.00-12.30$ & Penutup & Panitia \\
\hline \multicolumn{3}{|c|}{ Rabu, 11 November 2020} \\
\hline $08.00-08.15$ & Pembukaan & Mc : Agustina Mogi, S.Si., M.S.M. \\
\hline $08.15-08.45$ & Pengarahan Ketua Pelaksana & Rudi Sanjaya, S.E., M.M. \\
\hline $08.45-11.30$ & $\begin{array}{l}\text { Pelatihan virtual pembuatan } \\
\text { Laporan Keuangan LAZ } \\
\text { Nahwa Nur untuk menarik } \\
\text { muzakki berdonasi }\end{array}$ & Arif Surahman, S.E., M.S.M. \\
\hline $11.30-12.00$ & Sesi Tanya jawab & Agustina Mogi, S.Si., M.S.M. \\
\hline $12.00-12.30$ & Penutup & Mahasiswa \\
\hline \multicolumn{3}{|c|}{ Kamis, 12 November 2020} \\
\hline $08.00-08.30$ & $\begin{array}{l}\text { Pembukaan dan Review } \\
\text { Materi }\end{array}$ & Mc : Sulistiyani, S.Pd., M.Pd. \\
\hline $08.30-10.30$ & $\begin{array}{lc}\text { Pelatihan virtual pembuatan } \\
\text { Laporan } & \text { Keuangan LAZ }\end{array}$ & Arif Surahman, S.E., M.S.M. \\
\hline
\end{tabular}




\begin{tabular}{cll}
\hline WAKTU & \multicolumn{1}{c}{ URAIAN KEGIATAN } & \multicolumn{1}{c}{ KETERANGAN } \\
\hline & $\begin{array}{l}\text { Nahwa Nur untuk menarik } \\
\text { muzakki berdonasi }\end{array}$ & \\
\hline $10.30-11.00$ & Sesi Tanya jawab & Panitia dan Peserta \\
\hline $11.00-11.15$ & $\begin{array}{l}\text { Penyerahan Souvenir kepada } \\
\text { Pengurus LAZ Nahwa Nur } \\
\text { secara simbolis via online }\end{array}$ & Rudi Sanjaya, S.E., M.M. \\
\hline $11.15-11.30$ & Foto Bersama secara virtual & Panitia dan Peserta \\
\hline $11.30-12.00$ & Kultum dan Doa Penutup & Joko Nugroho (Mahasiswa) \\
\hline
\end{tabular}

\section{Metode Kegiatan}

Metode kegiatan ini berupa pemberian tips dan trik kepada para peserta. Berikut ini adalah tahapan pelatihan yang dilakukan:

1). Tahap persiapan, Tahap persiapan yang dilakukan meliputi:

a. Survey awal,

b. Pemantapan dan penentuan lokasi dan sasaran. Setelah survey maka ditentukan lokasi pelaksanaan dan sasaran peserta kegiatan.

2). Tahap Pelaksanaan Pengabdian Kepada Masyarakat

Tahap ini kami memberikan metode pemberi materi dilakukan dengan ceramah, tanya jawab interaktif, demonstrasi dan penyelesaian kasus secara online melalui aplikasi zoom-meeting. Pembukaan dibuka oleh perwakilan LAZ Nahwa Nur dilanjutkan dengan sambutan dan selanjutnya perwakilan dari Dosen Unpam memberi sambutan dilanjutkan dengan pemberian materi kurang lebih selama 1 jam. Pada tahap ini akan diberikan penjelasan mengenai apa itu pelatihan virtual pembuatan laporan keuangan badan Lembaga Amil Zakat Nahwa Nur untuk menarik muzakki berdonasi. Sesi ini menitik beratkan pada pemberian penjelasan mengenai bagaimana penerapan pembuatan laporan keuangan badan Lembaga Amil Zakat Nahwa Nur untuk menarik muzakki berdonasi.

3). Tahap Pelatihan Untuk melaksanakan kegiatan tersebut digunakan beberapa metode pelatihan yaitu:
a. Metode ceramah
b. Metode tanya jawab
c. Metode simulasi

\section{HASIL DAN PEMBAHASAN}

\subsection{Tahap Persiapan}

1). Survei Awal

Kami melakukan survei kepada Badan LAZ Nahwa Nur yang menggalang dana untuk para kaum dhuafa yang membutuhkan dengan menarik calon para muzakki untuk berdonasi. Caranya dengan membuat Laporan Keuangan yang benar untuk mendapatkan kepercayaan para muzakki untuk tergerak menjadi donatur. 
2). Pemantapan dan penentuan lokasi dan sasaran

Berdasar data awal ini maka tim pelaksana yakin bahwa pemberian pengetahuan dan keterampilan pembuatan laporan keuangan ini sangat tepat supaya dapat menarik para muzakki untuk berdonasi. Metode pelatihan yang digunakan adalah Metode ceramah, Metode tanya jawab secara mendalam dan metode demonstratif yang dilakukan secara virtual. Pelatihan ini dilaksanakan bersamaan dengan pemberian materi tentang perijinan dari pihak LAZ Nahwa Nur.

\section{Tahap Pelaksanaan Pengabdian Kepada Masyarakat}

Tahap ini kami memberikan memberikan penyuluhan dan bantuan informasi terkait pelatihan virtual pembuatan laporan keuangan badan Lembaga Amil Zakat Nahwa Nur untuk menarik muzakki berdonasi. Setelah itu, TIM PKM yang terdiri dari lima orang Dosen UNPAM melakukan Forum Group Discussion (FGD) untuk mempersiapkan pelaksanaan Pengabdian Kepada Masyarakat (PKM) untuk tanggal di SMP N 12 Tangerang Selatan.

Pelaksanaan Pengabdian Kepada Masyarakat di Lembaga Pemberdayaan Masyarakat pada tanggal $2-4$ November 2020. Tahap ini kami memberikan metode pemberi materi dilakukan dengan ceramah, tanya jawab interaktif, demonstrasi dan penyelesaian kasus secara online melalui aplikasi zoom-meeting. Pembukaan dibuka oleh perwakilan LAZ Nahwa Nur dilanjutkan dengan sambutan dan selanjutnya perwakilan dari Dosen Unpam memberi sambutan dilanjutkan dengan pemberian materi kurang lebih selama 1 jam dengan tema "Pelatihan virtual pembuatan laporan keuangan badan Lembaga Amil Zakat Nahwa Nur untuk menarik muzakki berdonasi". Kegiatan ini di ketua oleh Bapak Rudi Sanjaya dengan narasumber Bapak Arif Surahman, Ibu Sulistiyani, Ibu Krida Puji Rahayu dan Ibu Agustina Mogi. Kegiatan PKM ini dihadiri kebanyakan dari kalangan pengurus administrasi LAZ Nahwa Nur, tenaga pendidik (guru), dan mahasiswa Pascasarjana Manajemen Universitas Pamulang.

\section{Tahap Pelatihan}

Untuk melaksanakan kegiatan tersebut digunakan beberapa metode pelatihan yaitu:

1). Metode ceramah

Metode yang digunakan dalam pelatihan SDM dimulai dengan memberikan ceramah atau presentasi dengan tema "Pelatihan virtual pembuatan laporan keuangan badan Lembaga Amil Zakat Nahwa Nur untuk menarik muzakki berdonasi", dengan narasumber Bapak Arif Surahman yang dibantu oleh Ibu Sulistiyani sebagai moderator.

Adapun materi yang disampaikan adalah sebagai berikut. 


\section{Laporan Keuangan Entitas Non Laba \\ Oleh : Arif Surahman}

Gambar 1 Foto Materi Pelatihan Virtual Pembuatan Laporan Keuangan

\section{Untuk Apakah Laporan Keuangan?}

Pengguna laporan keuangan entitas berorientasi nonlaba pada umumnya memiliki kepentingan untuk menilai :

A. cara manajemen melaksanakan tanggung jawab atas penggunaan sumber daya yang dipercayakan kepada mereka.

B. Informasi mengenai posisi keuangan, kinerja keuangan dan arus entitas yang bermanfaat pada pembuatan keputusan ekonomi.

C. Kemampuan entitas non laba dalam menggunakan sumberdaya yang dikomunikasikan melalui laporan keuangan.

Gambar 2 Foto Materi Pelatihan Virtual Pembuatan Laporan Keuangan

2). Metode tanya jawab

Setelah sesi ceramah sudah selesai, maka dilanjutkan dengan sesi tanya jawab. Faktanya, peserta sangat antusias untuk menanyakan bagaimana cara Pelatihan virtual pembuatan laporan keuangan badan Lembaga Amil Zakat Nahwa Nur untuk menarik muzakki berdonasi.

3). Metode simulasi

Pelatihan ini juga diberikan metode simulasi, sehingga peserta langsung dapat mempraktekan apa yang sudah disampaikan. Apabila ada kendala maka langsung dibantu pada saat pelaksanaan PKM. Simulasi penting dilakukan untuk mengetahui seberapa besar tingkat pengetahuan dan ilmu yang diserap pada saat pelatihan.

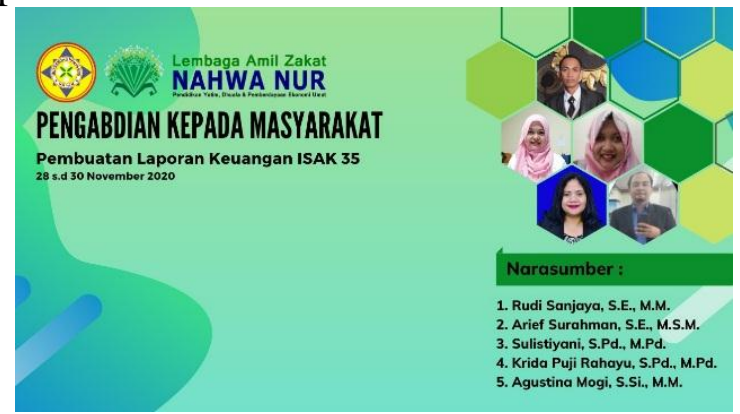

Gambar 3 Foto Kegiatan Pengabdian Kepada Mayarakat 


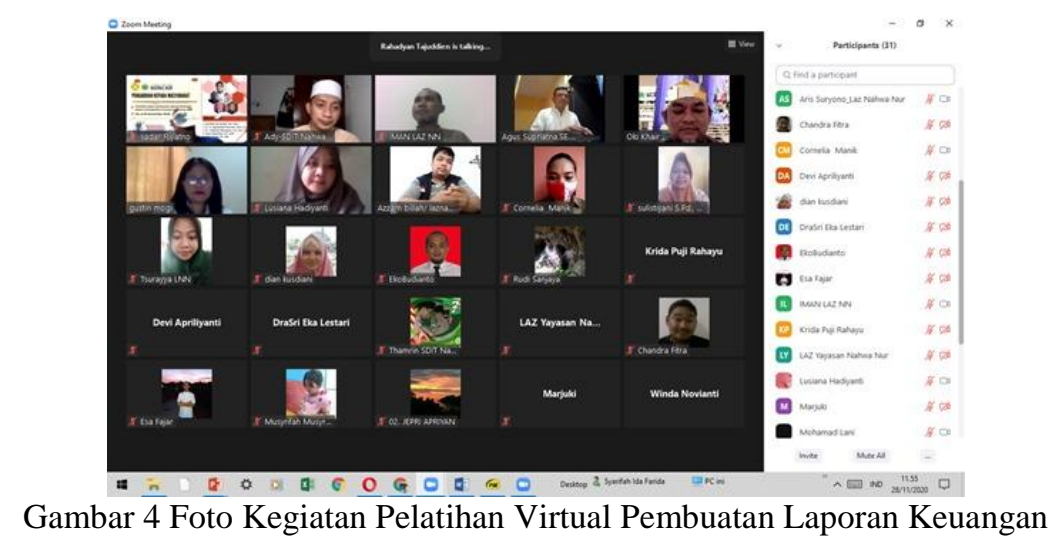

\section{SIMPULAN}

Berdasarkan pengamatan secara kualitatif terhadap umpan balik (feedback) angket digital yang diisi oleh peserta, dapat disimpulkan:

1). Kepercayaan merupakan faktor penting dalam menumbuhkan kesadaran, kepatuhan dan motivasi masyarakat Muslim dalam menunaikan kewajiban ZISnya melalui organisasi resmi atau formal (BAZNAS dan LAZ). Semakin tinggi kepercayaan umat terhadap OPZ maka akan semakin tinggi pula kesadaran, kepatuhan dan motivasi mereka untuk secara sukarela menyalurkan ZISnya ke OPZ formal.

2). Untuk menghasilkan suatu laporan keuangan ZIS yang baik, maka dibutuhkan penerapan sistem akuntansi yang baik pula.

\section{DAFTAR PUSTAKA}

Anshori, G. A. (2006). Hukum dan Pemberdayaan Zakat, Cetakan Pertama. Yogyakarta: Pilar Media.

Eliyani, C., Rahayu, K.P., Aesah, S., dkk. (2020). Pelatihan dan Bantuan Dalam Program Pemberdayaan Ekonomi Pada Masa Pandemi Covid-19 di RT 003/RW 006, Desa Kabasiran, Kecamatan Parung Panjang, Kabupaten Bogor. Indonesian Journal of Society Engagement, Vol. 1 No. 1, 151-164.

Hariningsih. (2006). Sistem Informasi Akuntansi. Edisi Pertama. Yogyakarta: Ardana Media.

Ikatan Akuntan Indonesia. (2007). Pernyataan Standar Akuntansi Keuangan Nomor 45. Jakarta: IAI.

Ikatan Akuntan Indonesia. (2011). Pernyataan Standar Akuntansi Keuangan Nomor 109. Jakarta: IAI.

Lativa, Sanjaya, R., dkk. (2020). Pelatihan Perhitungan Pajak Pph Pasal 21, Pasal 23, dan Pph Pasal 4 Ayat 2 Kepada Kepala Sekolah, Bendahara, Administrasi SMP Kota Tangerang Selatan Gugus 02. Jurnal DEDIKASI, Vol. 1, No. 1, 80-85. 
Mogi, A., Rahayu, K.P., Sanjaya, R., dkk. (2020). Bantuan Sosial Bagi Warga Terdampak Covid-19 Kampung Parigi RW 005. Jurnal Abdi Masyarakat Humanis, Vol. 2 No. 1, 14-19.

Mulyadi. (2001). Sistem Akuntansi. Cetakan Ketiga. Jakarta: Salemba Empat.

Nurhayati, Sri dan Wasilah. (2013). Akuntansi Syariah di Indonesia. Jakarta: Salemba Empat.

Rahayu, K.P. (2018). Menumbuhkan Intensi Berwirausaha Pada Mahasiswa Manajemen Universitas Pamulang, Jurnal Pemasaran Kompetitif, Vol. 1 (3) (125-135).

Rahayu, K.P., (2018). Pengaruh Web Based Learning terhadap Hasil Belajar Ditinjau dari Self-Directed Learning. Jurnal SAP (Susunan Artikel Pendidikan), Vol. 2, No. $3,249-254$.

Rahayu, K.P. (2020). Penerapan Metode Kasus Terhadap Hasil Belajar Pada Materi KSP, Jurnal Teladan: Jurnal Ilmu Pendidikan Dan Pembelajaran, Vol. 5 (2) (89-96).

Rahayu, K.P. (2020). Analisis Potensi Literasi Informasi Mahasiswa Prodi Manajemen Universitas Pamulang, Jurnal Teladan: Jurnal Ilmu Pendidikan Dan Pembelajaran, Vol. 5 (2) (89-96).

Rahayu, K.P. \& Sanjaya, R. (2020). Penerapan Path Analysis Model Mediasi Terhadap Faktor Yang Mempengaruhi Prestasi Belajar Mahasiswa. EDUKA: Jurnal Pendidikan, Hukum, Dan Bisnis, Vol. 5 (2) (87-103).

Rahayu, K.P., Wati, R., Prihanto, Y., dkk. (2020). Pelatihan Audit Internal Penggunaan Dana Bos untuk Kepala Sekolah, Bendahara, Administrasi SMP Kota Tangerang Selatan Gugus 03. Jurnal DEDIKASI, Vol. 1, No. 2, 6-12.

Sanjaya, R. (2020). The Impact of Source and Use of Funds on Liquidity at PT. Mustika Ratu Tbk. Jurnal SEKURITAS (Saham, Ekonomi, Keuangan dan Investasi), Vol. 3 (2) (158-165).

Sanjaya, R. (2019). The Influence of Ratio Analysis to The Dividend Payout Ratio and Its Impact on The Value of The Company Listed On The Malaysia Stock Exchange. Economic \& Accounting Journal, Vol. 2 (2) (95-103), Universitas Pamulang.

Sanjaya, R. \& Rahayu, K.P. (2020). The Influence of Fundamental Factors and Macroeconomics Against Dividend Payout Ratio and Company Value in LQ45 Non-Banking Registered Companies on the Indonesia Stock Exchange. Journal of Research in Business, Economics, and Education, Vol. 2 (5) (1053-1065).

Sanjaya, R. \& Rahayu, K.P. (2020). The Influence of Fundamental Factors of Macroeconomics Against Price Earning Ratio through Dividend Payout Ratio for LQ. 45 Non-Banking Companies. Jurnal SEKURITAS (Saham, Ekonomi, Keuangan dan Investasi), Vol. 4 (1) (80-95).

Undang-Undang Republik Indonesia Nomor 23 Tahun 2011 Tentang Pengelolaan Zakat. 